\title{
GURU MELEK TEKNOLOGI: PELATIHAN PEMBUATAN MEDIA BERBASIS MACROMEDIA FLASH
}

\author{
Elfi Rahmadhani \\ Jurusan Tarbiyah, Program Studi Tadris Matematika STAIN Gajah Putih Takengon \\ elfirahmadhaniestain-gp.ac.id
}

\begin{abstract}
Abstrak
Perkembangan teknologi yang semakin pesat sekarang ini, menuntut para guru untuk melek dengan teknologi. Untuk itu dibutuhkan suatu pelatihan yang diberikan kepada guru untuk membantu mereka mengembangkan dan meningkatkan kemampuan mereka terutama dalam membuat media pembelajaran berbasis komputer. Kegiatan pengabdian pada masyarakat ini bertujuan untuk memberikan pelatihan pembuatan media berbasis Macromedia Flash bagi guru-guru SMA/MA di Takengon. Metode yang digunakan dalam pengabdian ini adalah berupa pemberian materi dasar Macromedia Flash, latihan/praktek pembuatan media pembelajaran dan presentasi media pembelajaran yang telah dibuat oleh peserta. Ada dua evaluasi yang dilakukan dalam pengabdian ini, yaitu evaluasi kemampuan guru dalam membuat media pembelajaran berbasis Macromedia Flash dengan mempresentasikan media yang telah dibuat guru dan evaluasi kegiatan pelatihan yang telah dilakukan dengan menganalisis angket yang diberikan kepada peserta. Berdasarkan hasil analisis dari angket yang diberikan kepada peserta pelatihan, diketahui bahwa peserta merasa terbantu sekali dengan diadakannya pelatihan ini. Karena dengan pelatihan ini, guru dapat membuat media yang lebih menarik dan interaktif yang dapat digunakan dalam menjelaskan materi pelajaran di kelas. Mereka pada umumnya meminta perpanjangan waktu pelatihan, karena menurut mereka masih banyak ilmu yang bisa mereka dapatkan dari pelatihan ini.
\end{abstract}

Kata Kunci : media, macromedia flash

\section{PENDAHULUAN}

Pada zaman sekarang ini sudah seharusnya seorang guru melek dengan teknologi. Dengan memanfaatkan teknologi yang ada, seorang guru dapat meningkatkan kemampuan dan pengetahuannya. Karena pada dasarnya perkembangan teknologi memudahkan dan meningkatkan mutu kehidupan manusia khususnya dalam dunia pendidikan. Proses pembelajaran akan berpengaruh dengan perkembangan teknologi yang pesat saat ini. Terdapat lima pergeseran dalam proses pembelajaran dengan adanya perkembangan teknologi, yaitu 1) konsep pelatihan beranjak ke penampilan, 2) lokasi yang statis di ruang kelas dan lingkungan sekolah, berubah menjadi dimana saja dan kapan saja, 3) paradigma paper based berubah menjadi less paper dengan menggunakan media online, 4) fasilitas fisik ke fasilitas jaringan kerja dan 5) dari waktu siklus ke waktu nyata (Rosenberg, 2001). Selain itu, komunikasi dan interaksi antara guru dan siswa tidak hanya dilakukan melalui tatap muka saja, melainkan menggunakan media telepon, internet, e-mail dan media sosial lainnya.

Seorang guru dituntut agar dapat menciptakan lingkungan belajar yang kondusif dan melakukan program pengembangan professional. Guru diharapkan memiliki kemampuan dalam bidang studi yang ditekuninya, memiliki keterampilan memahami kurikulum, menguasai ragam metodologi penilaian, menciptakan lingkungan belajar yang kondusif dan melakukan pengembangan professional (Ono \& Ferriera, 2010). Sesuai dengan kurikulum 2013, siswalah yang seharusnya lebih aktif, guru hanya berperan sebagai fasilitator, mediator dan motivator. Sebagai fasilitator, seorang guru dituntut untuk kreatif dan inovatif dalam memanfaatkan dan menciptakan media pembelajaran. Oleh karena itu, guru harus dapat menyampaikan materi dengan menarik, efektif dan efisien, salah satunya dengan memanfaatkan media komputer/multimedia. Dalam hal ini penulis melihat masih ada sebagian guru yang belum menggunakan media berbasis komputer dalam membantu menyampaikan materi pelajaran di sekolah, sehingga para guru tersebut perlu dikenalkan lagi dengan media berbasis komputer. Media komputer yang pernah digunakan guru sebatas power point dan itu juga tidak rutin. Ketika diwawancarai para guru terlihat asing dengan multimedia yang penulis tunjukkan. Hal ini membuat penulis merasa perlu dilakukan suatu kegiatan berupa pelatihan pembuatan media berbasis komputer/multimedia 
bagi guru matematika untuk membantu mereka dalam menyampaikan materi pelajaran.

Multimedia merupakan penggunaan komputer untuk menyajikan dan menggabungkan teks, suara, gambar, animasi dan video dengan alat bantu bernavigasi, berinteraksi, berkarya dan berkomunikasi (Satria, 2005). Menurut Sadiman (2010) ada empat manfaat menggunakan media interaktif dalam pembelajaran, diantaranya adalah 1) untuk memperjelas penyajian pesan agar tidak terlalu bersifat verbalitas, 2) mengatasi keterbatasan ruang, waktu dan daya indera, 3) mengatasi sifat pasif siswa, dan 4) mempermudah guru dalam menyampaikan isi materi pelajaran. Salah satu jenis multimedia adalah Macromedia Flash.

Macromedia Flash merupakan perangkat lunak yang dapat digunakan untuk membuat sebuah animasi. Animasi adalah "susunan objek yang diatur sedemikian rupa sehingga menghasilkan suatu gerakan yang mampu menarik setiap orang untuk melihatnya" (Astuti, 2006). Sejalan dengan itu, Janu (2006) mengatakan bahwa Macromedia Flash merupakan sebuah program animasi interaktif berbasis vector yang memiliki fasilitas action script (suatu perintah yang menghasilkan suatu aksi atau gerakan/objek). Action script merupakan bahasa pemrograman sederhana yang dibuat untuk memudahkan para flash developer mengontrol timeline, suara, gambar, warna dan elemen lainnya yang memungkinkan animasi menjadi lebih interaktif karena file output dari flash dapat berjalan sesuai dengan script yang dimasukkan. Penggunaan Macromedia Flash dapat membantu guru dalam menjelaskan materi pelajaran yang diharapkan dapat membuat siswa lebih mudah mengingat materi yang diajarkan, dan memberikan pengalaman baru bagi siswa agar mereka termotivasi dalam pembelajaran.

Di dalam Macromedia Flash terdapat beberapa fasilitas yang dapat digunakan untuk membuat aplikasi, yaitu 1) animasi, dapat digunakan untuk membuat banner, media player, kartun, 2) game, dibuat dengan mengkombinasikan animasi dan action script, dan 3) user interface, digunakan untuk merancang website (Wahono, 2006). Melalui penggunaan Macromedia Flash ini diharapkan siswa lebih tertarik dan paham dengan materi pelajaran yang diberikan oleh guru mereka.

Kegiatan pengabdian pada masyarakat ini bertujuan untuk menambah keterampilan dan pengetahuan guru dalam mengoptimalkan media pembelajaran khususnya media komputer serta untuk mensosialisasikan perangkat lunak Macromedia Flash kepada para guru matematika di Takengon.

\section{TARGET DAN LUARAN}

1. Target dari kegiatan pengabdian ini adalah:

a. Melatih para guru agar mampu membuat program aplikasi komputer lainnya untuk membantu penyampaian materi pelajaran.

b. Mensosialisasikan software Macromedia Flash kepada guru matematika.

c. Meningkatkan keterampilan dan pengetahuan guru akan pemanfaatan media pembelajarn berbasis komputer terutama menggunakan Macromedia Flash.

2. Luaran dari kegiatan pengabdian ini adalah: para guru mampu membuat media pembelajaran dengan menggunakan software Macromedia Flash.

\section{METODE PELAKSANAAN}

Kegiatan pengabdian pada masyarakat ini terdiri dari beberapa tahapan, yaitu:

\section{Persiapan.}

Sebelum melakukan pelatihan, ada beberapa persiapan yang harus dilakukan oleh tim pengabdian, yaitu

a. Koordinasi dengan mitra mengenai berapa jumlah peserta, waktu dan tempat melaksanakan pelatihan

b. Mempersiapkan alat dan bahan yang diperlukan untuk pelatihan seperti komputer/laptop, Infocus, materi pelatihan, modul, software Macromedia Flash dll.

\section{Pelaksanaan kegiatan.}

Metode yang digunakan dalam kegiatan pengabdian pada masyarakat ini adalah berupa pemberian pelatihan kepada para peserta. Pelatihan ini terdiri dari dua tahap, yaitu pelatihan dasar animasi menggunakan Macromedia Flash, dan latihan serta presentasi media pembelajaran yang dibuat oleh peserta. Para peserta pelatihan dibekali dengan modul Macromedia Flash untuk memandu mereka dalam memahami cara menggunakan software Macromedia Flash tersebut. Secara lebih rinci kegiatan-kegiatan yang dilakukan pada pengabdian ini adalah sebagai berikut: 
a. Pertama para peserta akan diberikan modul tentang penggunaan Macromedia Flash. Peserta akan diperkenalkan terlebih dahulu dengan fitur Macromedia Flash dan tools yang ada didalamnya yang dapat digunakan dalam pembuatan media pembelajaran.

b. Kedua, tim akan menjelaskan teknik dasar pembuatan media pembelajaran matematika menggunakan Macromedia Flash.

c. Ketiga, tim memberikan beberapa contoh media pembelajaran matematika yang menggunakan Macromedia Flash.

d. Keempat, peserta diberikan waktu untuk latihan mandiri membuat media pembelajaran matematika dasar dengan bimbingan dari tim.

e. Kelima, media pembelajaran yang telah dibuat oleh guru dipresentasikan untuk melihat pemahaman peserta terhadap materi yang diberikan.

\section{Evaluasi.}

Evaluasi dari kegiatan pengabdian pada masyarakat ini didapatkan dengan cara:

a. Evaluasi kemampuan dan keterampilan peserta. Evaluasi ini diukur dengan melihat apakah peserta sudah mampu membuat media pembelajaran matematika yang menarik dan interaktif.

b. Evaluasi kegiatan pengabdian pada masyarakat. Evaluasi ini didapatkan dengan memberikan angket kepada seluruh peserta untuk melihat apakah kegiatan yang dilakukan berhasil atau tidak.

\section{HASIL DAN PEMBAHASAN}

Peserta dalam kegiatan pengabdian ini adalah para guru-guru SMA/MA baik negeri maupun swasta yang berada di wilayah Takengon yang terdiri dari 20 orang guru. Kegiatan ini dilakukan di MAN 2 Takengon, mengingat sekolah tersebut memiliki laboratorium komputer yang dapat digunakan untuk kegiatan pengabdian ini. Kegiatan pelatihan dilakukan selama tiga hari yaitu pada hari Jum'at, Sabtu dan Minggu tanggal 7-9 September 2018 dengan rincian sebagai berikut:

1. Pada hari Jum'at, para peserta diberikan pengenalan mengenai multimedia dan Macromedia Flash. Materi yang diberikan berupa: mengenal animasi, menggambar bentuk dasar, menggunakan warna dan mengimpor gambar, membuat animasi objek bergerak, animasi teks berubah warna, memberi suara pada animasi, membuat tombol kontrol (play dan stop) untuk animai dan mempublish serta mengekspor file.

2. Pada hari Sabtu dan Minggu peserta diberi kesempatan untuk berlatih membuat media pembelajaran matematika dengan menggunakan Macromedia Flash. Dalam membuat media ini, para peserta dibimbing oleh tim pengabdian secara intensif. Para peserta dapat mengerjakan media tersebut secara kelompok. Pada umumnya peserta membuat media dengan mengambil materi Bangun datar dan bangun ruang, seperti bagaimana membuktikan rumus luas persegi panjang, segitiga dan bangun datar lainnya. Sementara untuk bangun ruang para peserta membuat media untuk memperlihatkan bagian diagonal ruang, diagonal bidang, dan pembuktian rumus volume dari bangun ruang seperti balok. Selain materi Geometri, ada juga peserta yang membuat media untuk materi Teorema Pythagoras, yaitu pembuktian rumus teorema Pythagoras. Setelah semua peserta menyelesaikan media sederhana yang mereka buat, maka saatnya untuk mempresentasikan media tersebut. Beberapa peserta diminta untuk mempresentasikan media yang telah mereka rancang untuk melihat perkembangan kemampuan mereka dalam menggunakan Macromedia Flash. Media yang telah ditampilkan akan mendapatkan masukan dari peserta lainnya, agar menghasilkan media pembelajaran matematika yang lebih bagus dan kreatif lagi. Semua peserta mendapatkan softcopy dari semua media yang telah dibuat sebagai bahan referensi yang digunakan dalam pembelajaran nantinya.

Kendala yang dialami tim selama kegiatan pengabdian ini adalah beberapa peserta belum terlalu mahir menggunakan komputer sehingga dalam kegiatan praktek/latihan membuat media pembelajaran, para peserta dibagi ke dalam beberapa kelompok agar saling membantu antar peserta dalam menghasilkan media yang lebih baik.

Beberapa karya media pembelajaran matematika menggunakan Macromedia Flash yang 
dibuat oleh peserta dapat dilihat pada gambargambar berikut ini.
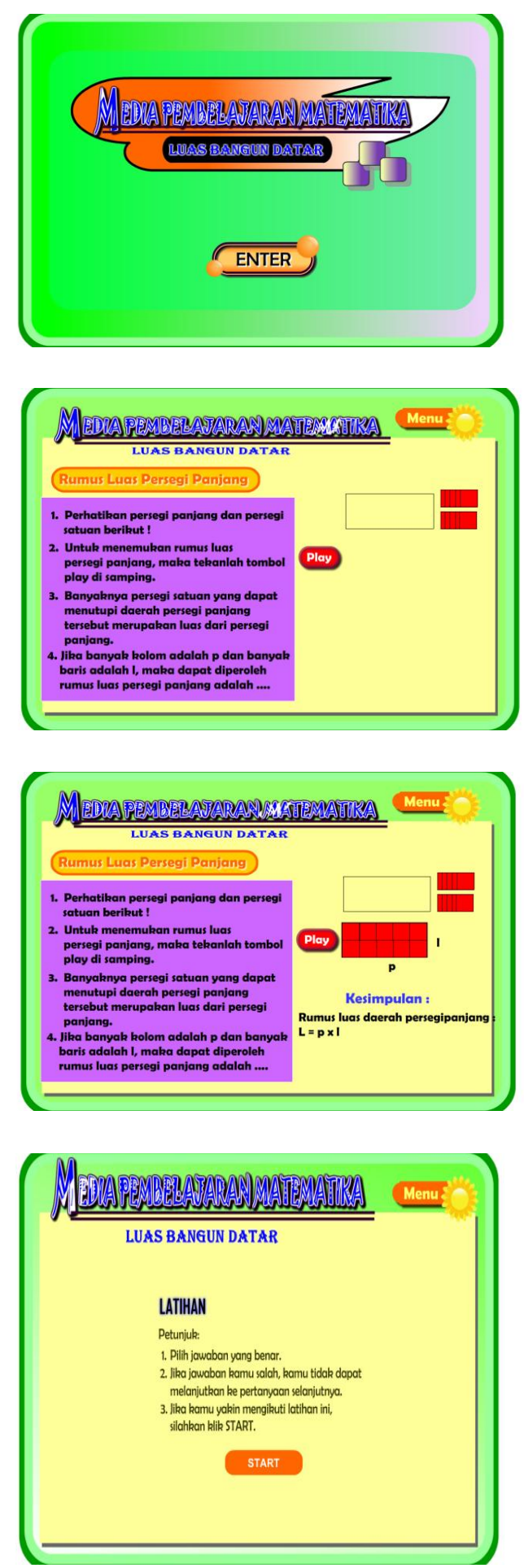

Gambar 1. Media Luas Bangun Datar
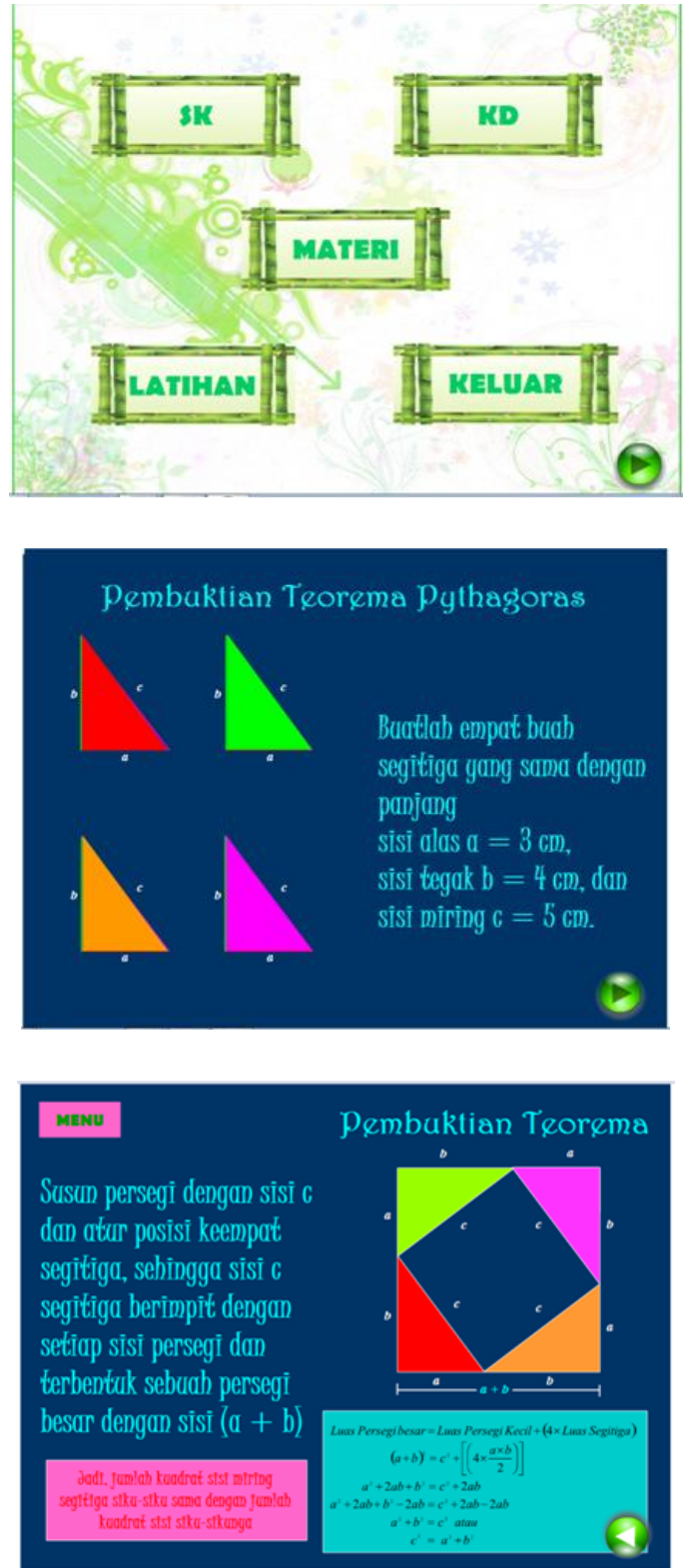

\section{Gambar 2. Media Pembuktian Teorema Pythagoras}

Sebelum kegiatan pengabdian pada masyarakat ini selesai, maka tim pengabdian memberikan angket kepada peserta untuk mengevaluasi kegiatan pelatihan yang telah dilakukan. Berdasarkan hasil analisis dari angket yang diberikan kepada peserta pelatihan, diketahui bahwa peserta merasa terbantu sekali dengan diadakannya pelatihan ini. Karena dengan pelatihan ini, guru dapat membuat media yang lebih menarik dan interaktif yang dapat digunakan dalam menjelaskan materi pelajaran di kelas. Mereka pada umumnya meminta perpanjangan waktu pelatihan, 
karena menurut mereka masih banyak ilmu yang bisa mereka dapatkan dari pelatihan ini.

\section{KESIMPULAN}

Berdasarkan hasil yang didapatkan selama melakukan kegiatan pengabdian pada masyarakat, maka diketahui:

1. Beberapa peserta belum pernah mengenal perangkat lunak yang diberikan sehingga butuh waktu lebih lama untuk menjelaskan Macromedia Flash ini.

2. Kegiatan pelatihan yang diberikan sangat bermanfaat bagi peserta terutama dalam meningkatkan kemampuan mereka membuat media pembelajran yang lebih kreatif dan interaktif. Peserta meminta perpanjangan waktu kegiatan pelatihan ini, karena menurut mereka masih banyak ilmu yang bisa mereka dapatkan dalam latihan ini.

3. Seluruh peserta terlihat sangat antusias dalam mengikuti pelatihan yang diberikan mulai dari sosialisasi, latihan dan presentasi.

\section{DAFTAR PUSTAKA}

1. Astuti, Dwi. 2006. Teknik Membuat Animasi Profesional Menggunakan Macromedia Flash 8. Yogyakarta: Andi Offset

2. Janu Media. 2006. About Flash. (Online). http://janumedia.com/classics/aboutflash.swf. diakses 3 Desember 2016

3. Ono, Y. dan Ferriera, J. 2010. A case study of continuing teacher professional development through lesson study in South Africa. South African Journal od Education. 30, pp. 59-74

4. Rosenberg. 2001. E-Learning: Strategies for Delivering Knowledge in The Digital Age. McGraw-Hill Professional Companies

5. Sadiman, A.S. 2010. Media Pendidikan. Jakarta: Rajawali Pers

6. Satria. 2005. Apa itu Multimedia. (online). www.satriamultimedia.com/artikel_apa_itu_mu ltimedia.html diakses 3 Desember 2016

7. Wahono. 2006. Multimedia sebagai Media Pembelajaran Interaktif. Semarang: Unnes Press 